\title{
A Novel Recombinant Protein Vaccine Containing the Different E7 Proteins of the HPV16, 18, 6, 11 E7 Linked to the HIV-1 Tat (47-57) Improve Cytotoxic Immune Responses
}

\section{Tahoora Mousavi}

Mazandaran, Iran https://orcid.org/0000-0003-2505-370X

\section{Reza Valadan}

Mazandaran Uni of medical sciences, Sari, Iran

\section{Alireza Rafiei}

Sari, Iran

\section{Ali Abbasi}

Sari, Iran

Mohammad Reza Haghshenas ( $\sim$ mhaghshenas@mazums.ac.ir)

Department of Microbiology, Molecular and Cell Biology Research Center, Faculty of Medicine, Mazandaran University of Medical Sciences, Sari, Iran

\section{Research Article}

Keywords: Fusion protein, E7, HPV vaccine, Therapeutic immunization, HIV1-Tat (47-57)

Posted Date: November 18th, 2020

DOl: https://doi.org/10.21203/rs.3.rs-106264/v1

License: (c) (i) This work is licensed under a Creative Commons Attribution 4.0 International License.

Read Full License 


\section{Abstract}

Objective: Human papillomavirus infection (HPV) is the most common viral infection which is causes of cervical, penal, vulvar, anal and, oropharyngeal cancer. E7 protein of HPV is a suitable target for induction of $T$ cell responses and controlling HPV-related cancer. The aim of the current study was to designed and evaluated a novel fusion protein containing the different E7 proteins of the HPV 16, 18, 6 and 11, linked to the cell-penetrating peptide HIV-1 Tat 49-57, in order to improve cytotoxic immune responses in in-vitro and in-vivo.

Methods: In this study whole sequence of HPV16,18,6,11 E7-Tat (47-57) and HPV16,18,6,11 E7 cloned into the vector and expressed in E.coli (BL21). The purified protein was confirmed by SDS page and western blotting and then injected into the C57BL/ 6 mice. The efficiency of the fusion protein vaccine was assessed by antibody response assay, cytokine assay (IL-4 and IFN- - ), CD+8 cytotoxicity assay and tumor challenge experiment.

Results: Result showed that fusion proteins containing Adjuvant (IFA,CFA) could express higher titer of antibody. Also, we showed that vaccination with E7-Tat and, E7-Tat-ADJ induced high frequencies of E7specific CD8+ T cells and CD107a expression as well as IFN- $y$ level and enhanced long-term survival in the therapeutic animal models.

Conclusion: Our finding suggested that this novel fusion protein vaccine was able to induce therapeutic efficacy and immunogenicity by improving CD8+ T cell in TC-1 tumor bearing mice; so this vaccine may be appreciated for research against HPV and tumor immunotherapies.

\section{Background}

Human papillomavirus infection (HPV) is the most common viral infection which is causes cancer or genital warts (1). Based on the location of HPV lesions, various types of cancer such as cervix, anal, vagina, throat, vulva, penis, and breast could be developed. More than 200 types of HPV have been identified, of which 40 types are belong to genital areas (2). HPV types are divided into high and low risk groups. Low-risk types such as 6 and 11 lead to $99 \%$ of genital warts and laryngeal papillomatosis; while $70 \%$ of cancers are related to high-risk types, such as $16,18(3)$.

The HPV virus belongs to papillomaviridae which is encoding two structural (L1, L2) and nonstructural protein (E1, E2, E4, E5, E6, and E7). E6 oncoprotein, is a key factor in tumor progression, act as P53 suppressor through binding to its $\mathrm{C}$-terminal region. This protein is a transcription factor that controls cell proliferation by preventing the $G_{1}$ to $S$ phase (4). E7 oncoprotein is a small nuclear protein with no enzymatic activity. This protein is bound to the hypophosphorylated retinoblastoma protein (PRb); in this situation, the cell cycle moves to the $S$ phase. Then, DNA synthesis and cell proliferation takes place (5). Regarding the importance of E6 and E7 in induction and maintenance of cellular transformation, these early genes have been reported as suitable targets for designing anti-tumor vaccines and controlling HPV 
In particular, dendritic cells (DCs) are one of the most important APCs and play an important role in immune response against viral infections (8). DCs function, macrophage-inflammatory protein-1a (MIP)-1a, MIP-1 $\beta$ and RANTES genes activation is associated with the high expression of MHC-I, CD40, CD80, CD86 and production of IL-1 $\beta$, TNF- $a$, IL-12, IL-15 cytokines (9). The serious problem associated with protein and peptide vaccines is that the structure of peptide antigen could be altered and do not elicit strong immune response (10). On the other hand, these proteins enter the cells via an endocytic and activate the MHC-II presentation pathway; so they are unable to induce strong cytotoxic CD $8+T$ cell response (11). Today, there are several ways are used to transfer protein in to the cell. Cell penetrate peptides (CPP) such as Tat, Pep-1, LAL, Cady-2, P28, hpp10 peptide with potential interact to proteins and peptides are able to transfer different types of cargo (protein and peptides) into the cell (12). It is suggested that a novel delivery system, Tat protein (small and soluble protein with 86-101 amino acids), with high efficiency and low cytotoxicity is able to transport peptides and proteins into cytoplasm via the plasma membrane and it is well-suited for the delivery of antigenic peptide to MHC-1 presentation pathway (13). Study shows that vaccination with Tat protein provides protection against viral replication, which can induce Th1 immune response as well as the Cytotoxic T lymphocytes (CTLs) response (14).

Prophylactic and therapeutic vaccination is highly effective in control and prevention of HPV infection. Two prophylactic HPV vaccines (Gardasil, Cervarix) are composed of L1 virus-like particles (VLPs) and they are used for the prevention of HPV infection and cervical cancer (15). In the current study, we designed a novel therapeutic vaccine based on E7 protein of HPV16,18,6,11 and Tat peptide against cervical cancer. HPV16, 18, 6, 11 E7- Tat (47-57) protein was assessed in vitro and examined for induction of E7-specific humoral and cell-mediated immune responses in C57BL/ 6 mice model. This study shows how a novel fusion protein induce therapeutic efficacy against HPV16-positive tumor cells in mice.

\section{Methods}

\section{Vaccine design and plasmid construction}

In brief, the nucleotide sequence of E7 genes from HPV6 (accession no. FR751338.1), HPV11 (accession no. JN644141.1), HPV18 (accession no. MF288727.1), and HPV16 (accession no. K02718.1) and Tat (YGRKKRRQRRR) were in silico assembled with appropriate linker (GGGS) using CLC Workbench 8.1. Whole sequence was synthesized by Biomatik, (Cambridge, Canada) and cloned into His-tag harboring pET-22b vector. In order to establish an additional fusion protein by the lack of Tat sequence, Nco1 and Xho1 restriction sites were placed between the chief protein (E7-TAT) and then cloned to pET-28a vector. The plasmids pET22b-E7-TAT and pET28a-E7 were purified.

\section{Production of fusion proteins (E7-TAT, E7)}

Expression plasmids (pET-22b, pET-28a) were transformed to the E.coli (BL21) and cultured on LB broth containing specific antibiotics, and then incubated at $37^{\circ} \mathrm{C}$ by shaking $170 \mathrm{rpm}$. The OD was checked Loading [MathJax]/jax/output/CommonHTML/jax.js at $600 \mathrm{~nm}$. One milliliter of the culture without inducer was 
used as a negative control. The culture was induced by adding $0.1-0.5 \mathrm{mM}$ of Isopropyl-D-

thiogalactoside (IPTG) and incubated at $37^{\circ} \mathrm{C}$ for $16 \mathrm{~h}$. Harvest bacterial cells were centrifuged at $6000 \mathrm{~g}$ at $4{ }^{\circ} \mathrm{C}$ for $15 \mathrm{~min}$; then the supernatant discarded and cell pellet frozen at $-20^{\circ} \mathrm{C}$. After re-suspending pellet in the buffer solution, it is found that the expressed proteins aggregated in inclusion bodies. The next day bacteria were re-suspended in buffer [50 mM Tris-HCL PH $=7.5,1.5 \mathrm{M} \mathrm{NaCl}, 20 \mathrm{mM}$ Imidazol, Urea $8 \mathrm{M}$, Guanidine $6 \mathrm{M}, 5 \mathrm{mM} 2 \mathrm{ME}$ and $2 \%$ Triton100x ]. Then cells were sonicated on ice for 3 min with $30 \mathrm{sec}$ interval. The mixture then centrifuged at $6000 \mathrm{~g}$ at $4{ }^{\circ} \mathrm{C}$ for $15 \mathrm{~min}$ and the soluble fraction was transferred to a new $15 \mathrm{ml}$ tube. At the final, $500 \mathrm{mM}$ Imidazol and affinity chromatography based on NiNTA (Qiagen) column were used for purification of the recombinant fusion protein using 6xHis-tag.

\section{SDS page and western blotting analysis}

After purification of recombinant fusion protein, dialysis was performed for the removal of residual salts, then concentration of protein was assessed by BCA kit (DNA Biotech, Iran) according to the manufacturer's instructions. After that, to confirm of the presence of purified protein, the fraction was analyzed by the $12 \%$ SDS-PAGE gels (w/v) and then transferred to a PVDF membrane for $2 \mathrm{~h}$ by Bio-Rad transfer system. PVDF membrane was shacked by TTBS (Tween $200.1 \%$, Tris base $1 \mathrm{M}, \mathrm{NaCl} 0.9 \%$ ) and $5 \%$ skimmed milk overnight. After washing with TTBS three times, the membrane treated with mouse anti-His-tag antibody (Thermo Fisher Scientific,US) at 1:1000 dilutions at room temperature (RT) by shacking $2 \mathrm{~h}$, and then washed with TTBS three times. The membrane was treated in the secondary HRPconjugated antibody (Thermo Fisher Scientific,US) at 1:5000 dilutions by shacking $2 \mathrm{~h}$ at RT; then it was washed with TTBS three times. The result was analyzed by staining with ECL and Luminescence Image System (Hansor, Taiwan).

\section{Cell culture}

TC-1 cells (expressing HPV16 E6 and E7 and generated by co-transformation of C57BL/6 mouse lung epithelial cells), KB cell (contain human papillomavirus18 (HPV18) and Caski cell (contain human papillomavirus16 (HPV16) sequences) were purchased from the Pasteur Institute of Iran. TC-1 cells were cultured in Dulbecco's modified Eagle's medium (DMEM) supplemented with $10 \%$ fetal bovine serum (FBS) and antibioticin a humidified atmosphere of $5 \% \mathrm{CO2}$. Caski and KB were cultured in Roswell Park Memorial Institute (RPMI) supplemented with $10 \%$ fetal bovine serum (FBS) and antibiotic in a humidified atmosphere of $5 \% \mathrm{CO} 2$.

\section{Preparation of cell lysate}

KB and Caski cells were De-attached and washed with PBS buffer for three times. The cells were centrifuged at $10000 \mathrm{~g}$ for $10 \mathrm{~min}$. After that the pellet were subjected to freeze-thaw between liquid nitrogen and $37^{\circ} \mathrm{C}$ water bath for 3-4 times. The amount of total protein was measured by BCA kit according to the manufacturer's instructions. In present study, HPV6 and HPV11 cell lysate were obtained from clinical sample.

\section{Mice immunization}


Inbred female C57BL/6 mice (8-12 weeks old) were purchased from the Pasteur Institute of Iran and maintained under specific pathogen free conditions. Six groups of mice $(n=4)$ were subcutaneously injected with $20 \mu \mathrm{g} / \mathrm{ml}$ E7-Tat, $20 \mu \mathrm{g} / \mathrm{ml}$ E7-Tat plus Freund's adjuvant (50: $50 \mathrm{v} / \mathrm{v}$ ), $20 \mu \mathrm{g} / \mathrm{ml}$ E7, $20 \mu \mathrm{g} / \mathrm{ml}$ E7 plus Freund's adjuvant (50: $50 \mathrm{v} / \mathrm{v}$ ), PBS and Freund's adjuvant at the right flank three times at 2-week intervals. Complete Freund's adjuvant (CFA) and incomplete Freund's adjuvant (IFA) were emulsified with protein for the 1 st and 2 nd respectively. Blood samples were obtained from the tail vein of mice before vaccination, two weeks after the second vaccination and one week after the last vaccination, for specific IgG antibody assay. (Table 1) (Fig. 1).

Table 1

vaccine formulation

\begin{tabular}{|c|c|c|c|c|}
\hline Groups & Regimen & Day 0 & Day 14 & Day 28 \\
\hline \multirow[t]{2}{*}{ G1 } & Protein/Tat/ADJ & HPV E7-Tat-CFA & HPV E7-Tat/IFA & HPV E7-Tat/ IFA \\
\hline & & $(20 \mu \mathrm{g} / \mathrm{ml}$ protein $)$ & $(20 \mu \mathrm{g} / \mathrm{ml}$ protein $)$ & $(20 \mu \mathrm{g} / \mathrm{ml}$ protein $)$ \\
\hline \multirow[t]{2}{*}{ G2 } & Protein/Tat & HPV E7-Tat & HPV E7-Tat & HPV E7-Tat \\
\hline & & $(20 \mu \mathrm{g} / \mathrm{ml}$ protein $)$ & $(20 \mu \mathrm{g} / \mathrm{ml}$ protein $)$ & $(20 \mu \mathrm{g} / \mathrm{ml}$ protein $)$ \\
\hline \multirow[t]{2}{*}{ G3 } & Protein/ADJ & HPV E7- CFA & HPV E7/ IFA & HPV E7/ IFA \\
\hline & & $(20 \mu \mathrm{g} / \mathrm{ml}$ protein $)$ & $(20 \mu \mathrm{g} / \mathrm{ml}$ protein $)$ & $(20 \mu \mathrm{g} / \mathrm{ml}$ protein $)$ \\
\hline G4 & Protein & E7 $(20 \mu \mathrm{g} / \mathrm{ml})$ & E7 $(20 \mu \mathrm{g} / \mathrm{ml}$ protein $)$ & E7 $(20 \mu \mathrm{g} / \mathrm{ml}$ protein $)$ \\
\hline G5 & Adjuvant & CFA $(100 \mu \mathrm{l})$ & IFA $(100 \mu \mathrm{l})$ & IFA $(100 \mu \mathrm{l})$ \\
\hline G6 & PBS & PBS $(100 \mu \mathrm{l})$ & PBS $(100 \mu l)$ & PBS $(100 \mu l)$ \\
\hline
\end{tabular}

\section{Antibody response assay}

Mice were sacrificed 10 days after the third immunization and the level of specific IgG antibody was measured by ELISA. $10 \mu \mathrm{g}$ of E7 and E7-Tat protein were coated with PBS buffer in 96 well plates (Nunc), overnight at $4{ }^{\circ} \mathrm{C}$. After washing with PBS buffer and Tween $20(5 \%)$ for 3 times, wells were blocked with $4 \% \mathrm{BSA}$ (bovine serum albumin) for $2 \mathrm{~h}$ at $37^{\circ} \mathrm{C}$. Then, after washing, serum samples were at 1:100 dilution were added to each well in triplicate and incubated for $1.5 \mathrm{~h}$ at RT. After washing, a goat antimouse IgG HRP antibody was added to each cell, and the plate was incubated for $1.5 \mathrm{~h}$ at RT. The plate was washed and TMB solution was added to each well. After $10 \mathrm{~min}$, stop solution (H2SO4 (2N)) was added and the absorbance was measured at $450 \mathrm{~nm}$.

\section{MTT assay for toxicity of HPV6 and HPV16 cell lysate}

The MTT assay was used for evaluation of the toxicity of clinical and cell lysate samples (HPV6 E7 and HPV16). Briefly, normal C57 BL/6 splenocytes (500,000/well in RPMI 1640 containing 10\% FBS) were seeded anto 9h-well culture nlates in trinlicate. After $24 \mathrm{~h}$ of culture, cells were stimulated with different Loading [MathJax]/jax/output/CommonHTML/jax.js 
doses of protein $(100 \mu \mathrm{g} / \mathrm{ml}, 50 \mu \mathrm{g} / \mathrm{ml}$, and $20 \mu \mathrm{g} / \mathrm{ml})$ and incubated. After $48 \mathrm{~h}$, the supernatants were removed and the MTT ([3-(4,5-dimethylthiazol-2-yl)-2,5-diphenyltetrazoliumbromide], Sigma, $5 \mathrm{mg} / \mathrm{mL}$ in PBS) was added. Then, cells were incubated at $37^{\circ} \mathrm{C}$ in $5 \% \mathrm{CO} 2$ for $4-6 \mathrm{~h}$. The absorbance of purple formazan crystal was measured at $590 \mathrm{~nm}$ by an ELISA reader after dissolution in dimethyl sulfoxide (DMSO), Sigma. MTT assay was performed in triplicates.

\section{cytokine assay (IL-4 and IFN-Y)}

After sacrificing the mice, the spleen of each mice was isolated. A total of $\left(5 \times 10^{5} / \mathrm{ml}\right)$ splenocytes were stimulated in triplicate with $100 \mu \mathrm{g} / \mathrm{ml}$ concentrations (16) of HPV6, HPV11, KB (HPV18), Caski (HPV16) cell lysate and $10 \mu / \mathrm{ml}$ of each purified protein (HPV E7 and HPV E7-Tat) in RPMI 1640 medium supplemented with $10 \%$ FBS and $100 \mu \mathrm{g}$ of streptomycin per $\mathrm{ml}$ for $48 \mathrm{~h}$ in a $37 \mathrm{C}, 5 \% \mathrm{CO} 2$ incubator. After that supernatant was collected for the presence of cytokines IL-4 and IFN- $y$. Concentration of cytokines were determined by specific sandwich ELISA-Reader according to the manufacturer's instruction. (Invitrogen, United States) with C.N 88-7044 (Mouse IL-4 Uncoated ELISA) and 88-7314 (Mouse IFN gamma Uncoated ELISA).

\section{$\mathrm{CD}+8$ cytotoxicity}

Splenocytes from each mouse harvested in cell medium at $5 \times 10^{5} / \mathrm{ml}$ and stimulated with $100 \mu \mathrm{g} / \mathrm{ml}$ concentrations of HPV6, HPV11, KB, Caski cell lysate and $10 \mu / \mathrm{ml}$ of each purified protein (E7 and E7-Tat) for $48 \mathrm{~h}$ in a $37 \mathrm{C}^{\circ}, 5 \% \mathrm{CO} 2$ incubator. Then the pellet were collected and labeled with FITC-conjugated anti-CD8a and PE-conjugated anti-CD107a antibody (invitrogen, USA) for cytotoxicity activity. We used isotype matched antibodies as control (Invitrogen, USA). Data were analyzed using Flowmax software (TreeStar, San Carlos, CA).

\section{Tumor model and vaccination}

For therapeutic studies six groups of mice $(n=4)$ challenged with $3 \times 10^{5}$ TC-1 cells subcutaneously in the right flank. On day 6 post-tumor, mice were challenge with various formulation of vaccine containing $20 \mu \mathrm{g} / \mathrm{ml}$ E7-Tat, $20 \mu \mathrm{g} / \mathrm{ml}$ E7-Tat plus Freund's adjuvant, $20 \mu \mathrm{g} / \mathrm{ml} \mathrm{E7,} 20 \mu \mathrm{g} / \mathrm{ml}$ E7 plus Freund's adjuvant, PBS and Freund's adjuvant on day 0, 14, 28 (Table 1). Following the tumor cells challenge, tumor length, width and depth was measured by manual calipers every week.

\section{Statistical Analysis.}

Statistical analysis was assessed using ANOVA (one-way and two-way) followed by Tukey's test (Graph Prism Pad version 8.0.1 soft-ware). Survival was analyzed using the log-rank (Mantel-Cox) test. This result considered statistically significant as a $P$ value of $<0.05$.

\section{Results}

\section{Identification of recombinant protein}


DNA fragments of the HPV 16,18,6,11 E7-Tat and the short TAT peptide insertion element, 'YGRKKRRQRRRS', were subcloned into the corresponding restriction sites of the $\mathrm{pET}-22 \mathrm{~b}$ plasmid. The construct of $\mathrm{pET}$-22b vector containing C-terminal HisTag and N-terminal Tat (47-57) (YGRKKRRQRRRS) is shown in Fig. 2 (A,B). HPVE7-Tat (47-57) digested with Nco1 and Xho1 is shown in Fig. 3.

\section{Expression and purification of the recombinant fusion protein}

The plasmid pET22b E7-Tat vector was purified and transformed into BL21. Fusion protein expression was induced by adding IPTG to LB broth media. For optimization of the protein expression, some various conditions were tested, such as temperature, concentration of IPTG, induction time of expression and host. This study shows that induction with $0.1-0.5 \mathrm{mM} \mathrm{IPTG}$ at $37^{\circ} \mathrm{C}$ for $16 \mathrm{~h}$ is suitable condition for expression of the fusion protein (Fig. 4.A,B). The sonicated cell supernatants were purified using $\mathrm{Ni2}+(\mathrm{Ni}-$ NTA superflow) affinity chromatography. Purification of HPVE7-Tat and HPVE7 protein with the molecular weight of 48.57 and $46.68 \mathrm{KDa}$ is shown in Fig. $5(\mathrm{~A}, \mathrm{~B})$. The purified recombinant protein transferred to PVDF membrane for western blotting analysis then, they were detected by anti-His antibody (Fig. 6. A,B). According to the BCA protein assay kit, the total concentration of protein was calculated $600 \mu / \mathrm{ml}$.

\section{Protective response elicited in E7-Tat-ADJ group}

According to this point that specific neutralizing antibodies are effective in preventing of HPV infection (17), in this study the sera from each vaccinated group treated with $10 \mu \mathrm{g} / \mathrm{ml}$ of the HPV E7-Tat and HPV E7 protein for examination of specific IgG antibody production against these proteins.

Analysis of specific IgG response with respect to HPV E7-Tat and HPV E7 protein in per group of mice immunized using ELISA in second immunization and third immunization. Figure $7(A, B)$. shows that the specific IgG level was significantly higher in vaccinated groups compared to ADJ and PBS after the second and third immunization (<0.0001). Our data shows that in vaccinated groups with E7 and E7-Tat protein in both group $A$ and $B$, the specific IgG level is increased after the third immunization. On the other hand, in vaccinated group with E7-Tat-ADJ, the level of antibody is reached to the maximum titration in the second immunization. Briefly, our finding shows that the mice immunized with E7-Tat-ADJ protein was able to stimulate strong IgG antibody with compared to other groups after the second and third immunization (<0.0001). Figure 7(C). We suggest that Adjuvant in combination with Tat peptide can be effective at elevating serum antibody level.

\section{The $100 \mu \mathrm{g}$ of cell lysate is the safe concentration for toxicity}

MTT was performed for measuring of toxicity effect of HPV16 and HPV6 cell lysates at different concentration. MTT assay shows that HPV16 and HPV6 cell lysates at ratio of $100 \mu \mathrm{g}$ did not induce 
toxic effects compared to $20 \mu \mathrm{g}$ and $50 \mu \mathrm{g}$ during $48 \mathrm{~h}$ period. It is interesting that there is no statistical difference were detected in toxicity rate between these groups (Fig. 8).

\section{IFN-y production increased in E7-TAT-ADJ vaccinated groups}

As we know, IFN-y plays a critical role in enhancing the innate and adaptive immune responses against tumor growth. Data indicates that vaccination is an important mechanism for IFN-y producing. In this present study we examined the protective IFN- $\gamma$ response in vaccination groups. The splenocyte of all vaccinated groups were stimulated with HPV16, HPV18, HPV6, HPV11 cell lysates, E7-Tat and E7 protein in-vitro. The results of IFN- $\gamma$ assay shows that the level of IFN- $\gamma$ in E7-TAT and E7-TAT-ADJ vaccinated groups were effectively increased in compared to other groups $(P<0.05)$. This result suggests that immunization of mice with E7-TAT-ADJ enhanced the specific immune response. (Fig. 9).

On the other hand, the splenocyte of all vaccinated groups were stimulated with HPV16, HPV18, HPV6, HPV11 cell lysates, HPV E7-Tat and HPV E7 protein and did not show IL-4 producing in any group (P > 0.05 , data not shown).

\section{E7-TAT-ADJ induced anti-tumor T cell response}

Study shows that CD107a expressing and IFN-y producing CD8 + T cell are important immune response against TC-1 tumors (18); so we examined whether immunization with the novel vaccine could induce E7specific cytotoxic activity. In the present study, two weeks after the third immunization, the splenocytes were harvested and the splenocytes of immunized animal were stimulated with E7-Tat, E7 protein and HPV16, HPV18, HPV6, HPV11 cell lysates. As shown in Fig. 10, the frequency of CD107a expression in E7TAT-ADJ vaccinated group was significantly higher than in the other groups. Our finding shows that the CTL response in the E7-TAT-ADJ immunized mice is highly effective and enhanced the antigen-specific immune response.

\section{Histopathological analysis}

For histopathological examination, tumor tissues were collected and immediately fixed with $10 \%$ neutral buffered formalin (NBF). The tissues were cut into 6 micron sections and stained with conventional hematoxylin and eosin (H\&E). Images were obtained by bright-light microscope (Fig. 11) .

\section{Therapeutic immunization of tumor-bearing mice with E7- Tat-ADJ and E7-TAT promote overall survival}

In the therapeutic strategy, the mice were immunized with E7-Tat, E7-Tat-ADJ, E7, E7-ADJ, PBS and Adjuvant for analysis of protection against tumor development. The results indicated that anti-tumor immune responses elicited by E7-Tat-ADJ and E7-TAT (Fig. 12). 
For determination of survival, tumor-bearing mice were monitored more than 40 days. Figure 14 shows that $100 \%(4 / 4)$ of animals treated with PBS and ADJ were moribund by day 35 . Moreover the treated groups with E7 and E7-ADJ, 100(4/4) animals were moribund by day 40-41. On the other hand, survival of TC-1-bearing mice treated with E7-Tat-ADJ and E7-TAT were significantly longer than other groups $50 \%$ $(2 / 4)$ over 45 day period. Our finding suggest that it was statistically significant differences between all vaccinated groups $(P<0.0001)$ (Fig. 13).

\section{Discussion}

In the current study of therapeutic vaccines, the HPV16,18,6,11 E7-Tat and HPV16,18,6,11 E7 recombinant fusion protein expressed in E.coli with the highest growth and protein synthesis rate. HPVs types encode two non-structural E6 and E7 oncoproteins which induce E6/E7-specific T cells. E6 protein inactivate tumor suppressor protein P53 and E7 protein bind to pRb which is responsible for the maintenance of the cell cycle (19). Our findings indicate that the recombinant fusion protein is able to induce cellular immune response and CTL activity. Similar to the present study, a review reported that DNA vaccination (VGX3100) using E7 and E6 protein is able to improve cellular and humoral immune responses, IFN- $\gamma$ production and CD $8+T$ cell activation in patients with HPV 16/18-positive CIN2/3 in a phase 1 clinical study (15).

It is well known that APCs capture exogenous antigens through phagocytosis and different mechanisms. The exogenous antigens can be presented on MHC class II. The processing of exogenous antigens by cytosolic pathway can be present by MHC-I and induce the production of specific CD8 + T cells (20). There are several strategies to increase antigen cross-presentation pathways, including the use of gp96 (21), fusionic (22), membrane protein A of Klebsiella pneumoniae (23), and cationic molecules. Tat fusion protein is safe and it is capable of binding antigens to the MHC-I and increases the production of antigenspecific CD $8+T$ cells; therefore it is used in cancer therapy, immunotherapy and therapeutic vaccines (24). This present study indicate that the Tat peptide of HIV-1 is essential for potentiating the induction of cell-mediated immunity. A result of study demonstrated that cationic proteins such as HIV-Tat sequences, is able to plays an important role for transferring proteins and drugs (20-200KD) to the mammalian cells (25). Another finding suggested that, protein vaccination conjugated Tat protein is able to improve CTL, IFN- $y$ and NK cells. Also it has been reported that E7 (49-57) Tat (49-57) nanoparticle plays an effective role to improve $\mathrm{CD} 8+\mathrm{T}$ cell-mediated antitumor immunity (26).

Freund's adjuvants are known as a delivery system and can be used to enhance the anti-tumor cellular immune responses. These Adjuvants are used in protein vaccines and able to increase the production of innate cytokines such as IFN-y, IL-12, IL-18, and IL-15 which are activated NK cell and CD107a expression (27). Freund's adjuvants alone are not insufficient for $C D 8+T$ cell priming and tumor regression. In the present research, it was demonstrated that Freund's adjuvants with TAT peptide in E7-TAT-ADJ vaccinated groups are potent adjuvants in priming of immune response and antitumor activity and also increase the survival of tumor-bearing mice. It has been shown that vaccination with HPV-16 cVLP containing CFA 
antibodies and suppresses tumor growth by production of tumor-specific CD4 + T cells (28). A research study indicated that immunization with L1, E6 and E7 protein plus CFA and IFA adjuvant is able to increases the prophylactic efficacy (29). Furthermore another findings suggested that vaccination with E7 and $L 1$ peptide combined with IFA adjuvant elicits a strong humoral and cellular immunity and increases the CD8 + T cell anti-tumor response and anti-HPV antibodies (30) (31).

Three types of HPV vaccines including Gardasil, Cervarix and Gardasil 9 based on L1 protein are prophylactic and can induce long-term immune responses. Because of the importance of cervical cancer in community, many research have focused on various therapeutic vaccines. This present results showed that HPV16,18,6,11 E7-Tat recombinant fusion protein with Freund's adjuvant is a novel vaccine which is able to increase CTL response and improve specific antibody in animal model. This vaccine let to increase survival rate by improving CD8 $+T$ cell; so it should be appreciate vaccine against HPV.

\section{Limitation}

The present study has some limitation. First whole-cell lysates were used instead of the pure protein for in-vitro stimulation of C57 BL/ 6 splenocytes. Second, for decrease both intra- and inter-assay variability, the number of mice should be increased. Third, different immunological testing via different techniques was the other limitation in this study.

\section{Declarations}

\section{Compliance with Ethical Standards}

Funding: This study was funded by Mazandaran University of Medical Sciences, Iran with grant No. 3049 and conducted in the Molecular and Cell Biology Research Center, Faculty of Medicine.

Conflict of interest: Author declares that no conflict of interest.

Ethical approval: All procedures performed in studies involving mice participants were in accordance with the ethical guideline of the International Council for Laboratory Animal Science (ICLAS) ( IR.MAZUMS.REC.96.3049). This article does not contain any studies with human participants performed by any of the authors.

\section{Acknowledgements}

None.

\section{Authors contributions}

Valadan Reza did most of the experiments and was a major contributor in writing the paper. Mousavi Tahoora and Abbasi Ali collected clinical tissues and performed the PCR assay. Rafiei Alireza performed 
the statistical analysis. Haghshenas Mohammad Reza designed the study and was also a major contributor in writing the paper. All authors read and approved the final manuscript.

\section{References}

1. Haghshenas MR, Mousavi T, Moosazadeh M, Afshari M. Human papillomavirus and breast cancer in Iran: a meta-analysis. Iranian journal of basic medical sciences. 2016;19(3):231.

2. Haghshenas MR, Mousavi T, Kheradmand M, Afshari M, Moosazadeh M. Efficacy of human papillomavirus 11 protein vaccines (cervarix and gardasil) in reducing the risk of cervical intraepithelial neoplasia: a meta-analysis. International journal of preventive medicine. 2017;8.

3. Akhondnezhad M, Haghshenas MR, Ghasemi M, Mousavi T. The prevalence and genotyping of human papillomavirus in patients with oral tumors in health centers and clinics of Mazandaran in Iran. VirusDisease. 2018;29(3):297-302.

4. Gulati T, Huang C, Caramia F, Raghu D, Paul PJ, Goode RJ, et al. Proteotranscriptomic measurements of E6-Associated Protein (E6AP) targets in DU145 prostate cancer cells. Molecular \& Cellular Proteomics. 2018:mcp. RA117. 000504.

5. Münger K, Androphy EJ, McBride AA. Regulation of the Papillomavirus E6 and E7 Oncoproteins By the Viral E1 and E2 Proteins. Viral Regulatory Structures And Their Degeneracy: CRC Press; 2018. p. 35-52.

6. Li J, Chen S, Ge J, Lu F, Ren S, Zhao Z, et al. A novel therapeutic vaccine composed of a rearranged human papillomavirus type 16 E6/E7 fusion protein and Fms-like tyrosine kinase-3 ligand induces CD8+ T cell responses and antitumor effect. Vaccine. 2017;35(47):6459-67.

7. Tang J, Yin R, Tian Y, Huang Z, Shi J, Fu X, et al. A novel self-assembled nanoparticle vaccine with HIV-1 Tat49-57/HPV16 E749-57 fusion peptide and GM-CSF DNA elicits potent and prolonged CD8+ T cell-dependent anti-tumor immunity in mice. Vaccine. 2012;30(6):1071-82.

8. Eagar TN, Miller SD. Helper T-cell subsets and control of the inflammatory response. Clinical Immunology (Fifth Edition): Elsevier; 2019. p. 235-45. e1.

9. Fanales-Belasio E, Moretti S, Nappi F, Barillari G, Micheletti F, Cafaro A, et al. Native HIV-1 Tat protein targets monocyte-derived dendritic cells and enhances their maturation, function, and antigenspecific T cell responses. The Journal of Immunology. 2002;168(1):197-206.

10. Du R-H, Liang L-R, Yang C-Q, Wang W, Cao T-Z, Li M, et al. Predictors of mortality for patients with COVID-19 pneumonia caused by SARS-CoV-2: a prospective cohort study. European Respiratory Journal. 2020;55(5).

11. Blum JS, Wearsch PA, Cresswell P. Pathways of antigen processing. Annual review of immunology. 2013;31:443-73.

12. Shahbazi S, Bolhassani A. Comparison of six cell penetrating peptides with different properties for in vitro and in vivo delivery of HPV16 E7 antigen in therapeutic vaccines. International Immunonharmacolnav $2018 \cdot 62 \cdot 170-80$.

Loading [MathJax]/jax/output/CommonHTML/jax.js 
13. Zou L, Peng Q, Wang P, Zhou B. Progress in research and application of HIV-1 TAT-derived cellpenetrating peptide. The Journal of membrane biology. 2017;250(2):115-22.

14. Alipour S, Mahdavi A, Abdoli A. The effects of CpG-ODNs and Chitosan adjuvants on the elicitation of immune responses induced by the HIV-1-Tat-based candidate vaccines in mice. Pathogens and disease. 2017;75(2).

15. Barra F, Leone Roberti Maggiore U, Bogani G, Ditto A, Signorelli M, Martinelli F, et al. New prophylactics human papilloma virus (HPV) vaccines against cervical cancer. Journal of Obstetrics and Gynaecology. 2019;39(1):1-10.

16. Kim C-H, Hong M-J, Park S-D, Kim C-K, Park M-Y, Sohn H-J, et al. Enhancement of anti-tumor immunity specific to murine glioma by vaccination with tumor cell lysate-pulsed dendritic cells engineered to produce interleukin-12. Cancer Immunology, Immunotherapy. 2006;55(11):1309-19.

17. Wu X, Ma X, Li Y, Xu Y, Zheng N, Xu S, et al. Induction of neutralizing antibodies by human papillomavirus vaccine generated in mammalian cells. Antibody Therapeutics. 2019;2(2):45-53.

18. Kim TG, Kim CH, Won EH, Bae SM, Ahn WS, Park JB, et al. CpG-ODN-stimulated dendritic cells act as a potent adjuvant for E7 protein delivery to induce antigen-specific antitumour immunity in a HPV 16 E7-associated animal tumour model. Immunology. 2004;112(1):117-25.

19. Su X, Xu W, Guan R, Wang Y, Wu J, Zhai L, et al. Adjuvant effect of docetaxel on HPV16 L2E6E7 fusion protein vaccine in a mouse model. International immunopharmacology. 2016;38:16-25.

20. Mellman I, Steinman RM. Dendritic cells: specialized and regulated antigen processing machines. Cell. 2001;106(3):255-8.

21. Singh-Jasuja H, Toes RE, Spee P, Münz C, Hilf N, Schoenberger SP, et al. Cross-presentation of glycoprotein 96-associated antigens on major histocompatibility complex class I molecules requires receptor-mediated endocytosis. Journal of Experimental Medicine. 2000;191(11):1965-74.

22. Laus R, Graddis TJ, Hakim I, Vidovic D. Enhanced major histocompatibility complex class Idependent presentation of antigens modified with cationic and fusogenic peptides. Nature biotechnology. 2000;18(12):1269.

23. Jeannin P, Renno T, Goetsch L, Miconnet I, Aubry J-P, Delneste Y, et al. OmpA targets dendritic cells, induces their maturation and delivers antigen into the $\mathrm{MHC}$ class I presentation pathway. Nature immunology. 2000;1(6):502.

24. Cafaro A, Tripiciano A, Picconi O, Sgadari C, Moretti S, Buttò S, et al. Anti-Tat Immunity in HIV-1 Infection: Effects of Naturally Occurring and Vaccine-Induced Antibodies Against Tat on the Course of the Disease. Vaccines. 2019;7(3):99.

25. Tanaka Y, Dowdy SF, Linehan DC, Eberlein TJ, Goedegebuure PS. Induction of antigen-specific CTL by recombinant HIV trans-activating fusion protein-pulsed human monocyte-derived dendritic cells. The Journal of Immunology. 2003;170(3):1291-8.

26. Zhao B, Wang Y, Zhang Y, Li Y, Zhang X, Xu Y, et al. TAT-mediated gp96 transduction to APCs enhances gp96-induced antiviral and antitumor T cell responses. Vaccine. 2013;31(3):545-52. 
27. Mousavi T, Saravi SS, Valadan R, Haghshenas MR, Rafiei A, Jafarpour H, et al. Different types of adjuvants in prophylactic and therapeutic human papillomavirus vaccines in laboratory animals: a systematic review. Archives of Virology. 2019:1-22.

28. Monroy-García A, Gómez-Lim MA, Weiss-Steider B, Hernández-Montes J, Huerta-Yepez S, RangelSantiago JF, et al. Immunization with an HPV-16 L1-based chimeric virus-like particle containing HPV-16 E6 and E7 epitopes elicits long-lasting prophylactic and therapeutic efficacy in an HPV-16 tumor mice model. Archives of virology. 2014;159(2):291-305.

29. Xu W-X, Wang J, Tang H-P, He Y-P, Zhu Q-X, Gupta SK, et al. Epitomics: IgG-epitome decoding of E6, E7 and L1 proteins from oncogenic human papillomavirus type 58. Scientific reports. 2016;6:34686.

30. Bates JT, Uematsu S, Akira S, Mizel SB. Direct stimulation of tlr5+/+ CD11 c+ cells is necessary for the adjuvant activity of flagellin. The Journal of Immunology. 2009;182(12):7539-47.

31. Levy 0 , Goriely S, Kollmann TR. Immune response to vaccine adjuvants during the first year of life. Vaccine. 2013;31(21):2500-5.

\section{Figures}

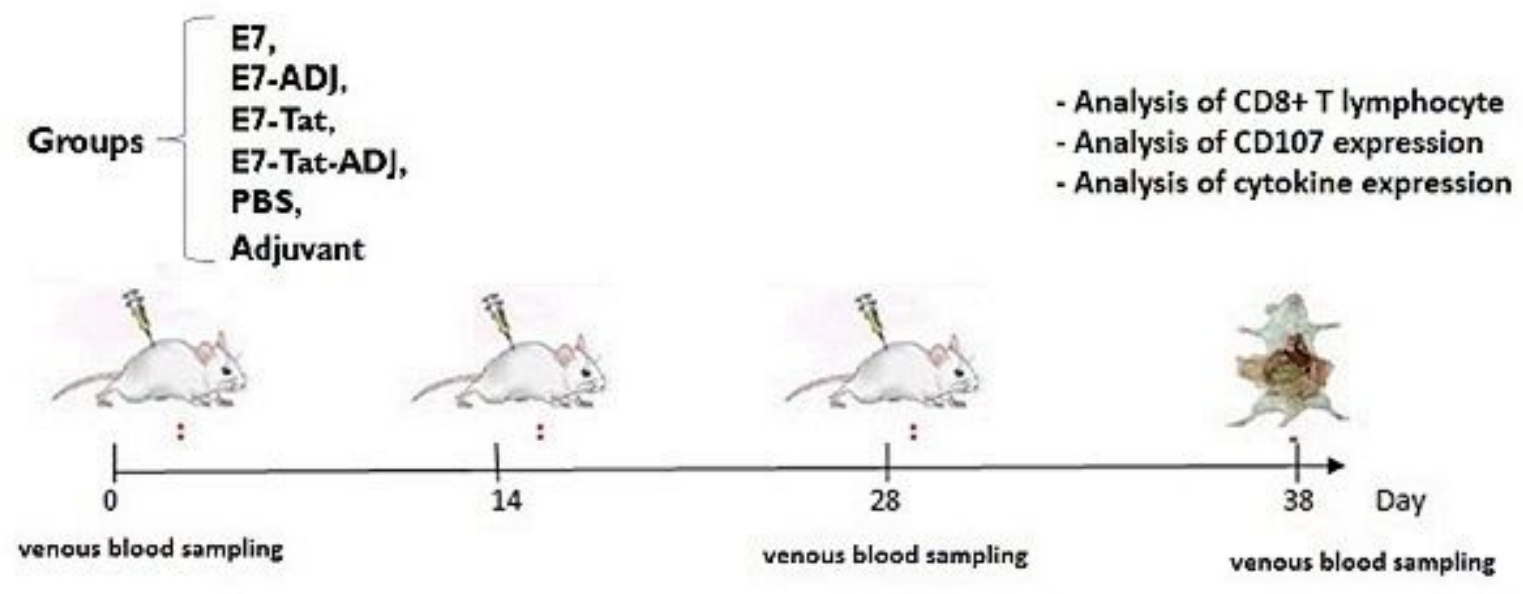

Figure 1

Mice immunization using different formulation 

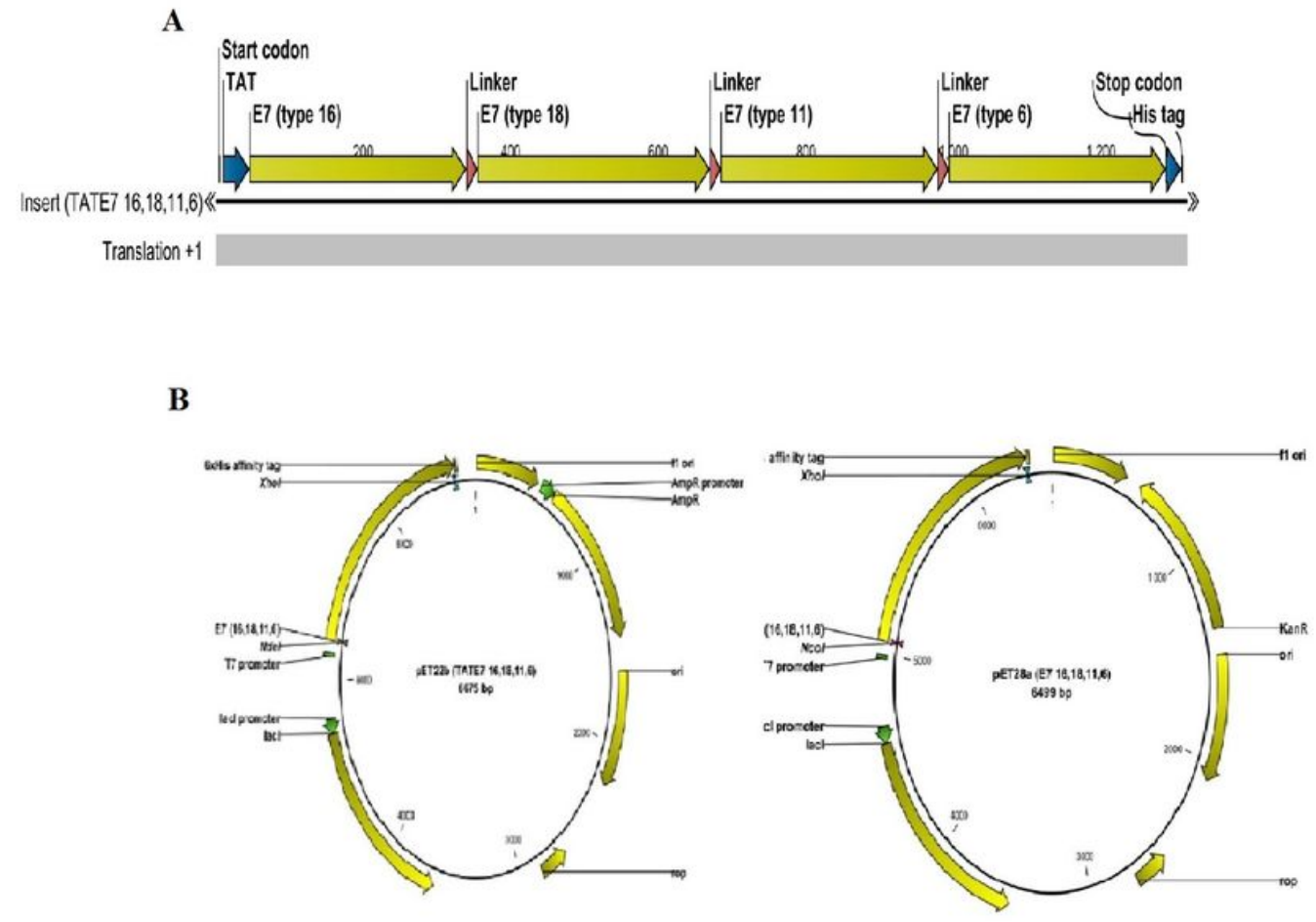

\section{Figure 2}

A: The construct of the HPV16,18,6,11 E7-Tat protein. The His-tags placed at the C-terminus and Tat sequence fused to N-terminus. B: The construct of pET-22b containing HPV16,18,6,11 E7-Tat gene and the construct of pET-28a containing HPV16,18,6,11 E7 gene. 


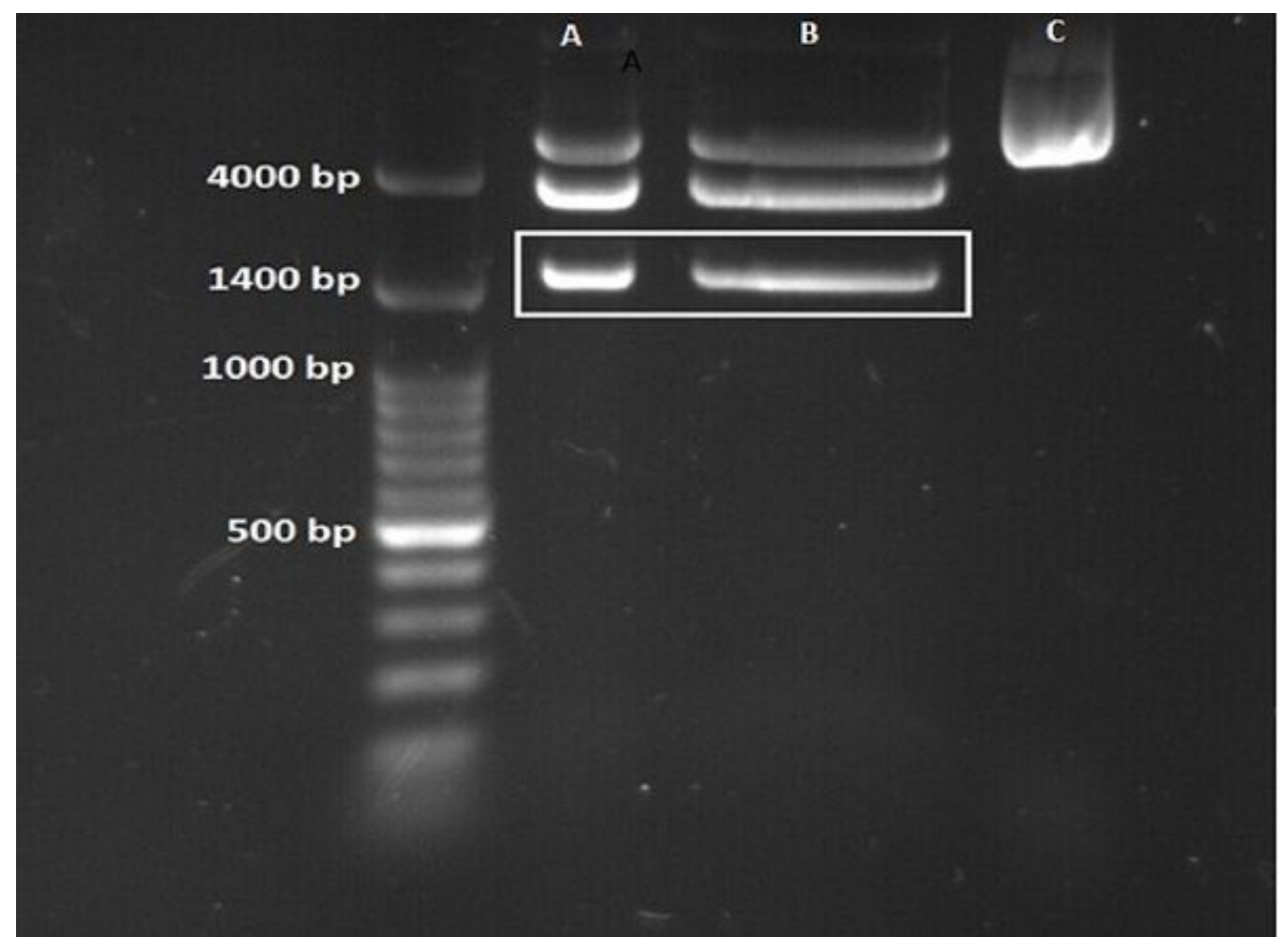

Figure 3

Digestion of pET-22b with Nco1 and Xhol for removal of Tat sequence. A, B: non-Tat sequence. C: Undigested (control).
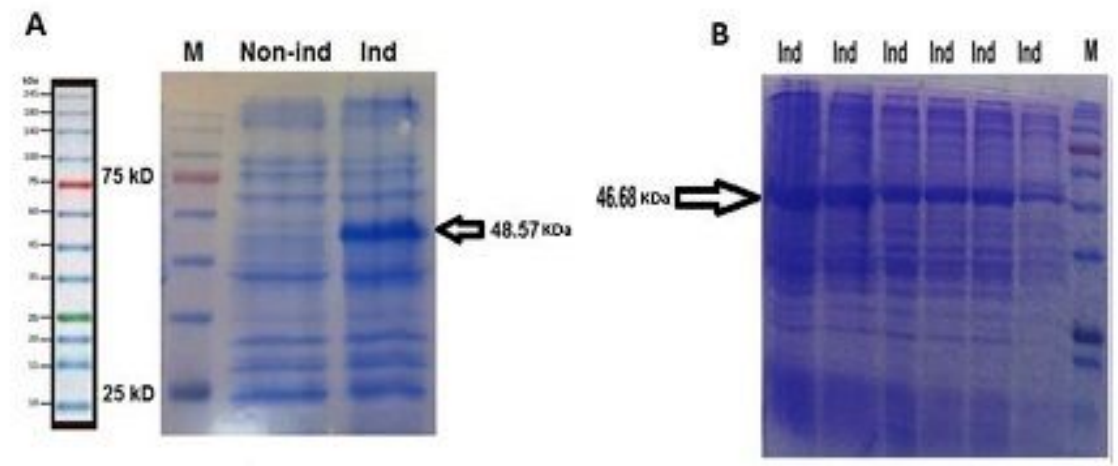

\section{Figure 4}

Protein expression and SDS-PAGE analysis of the HPV16,18,6,11 E7-Tat (48.57 KD) and HPV16,18,6,11 E7 protein (46.68 KD) expression. Lane M: protein marker (245 KD). Non-ind (Before IPTG induction); Ind 
A

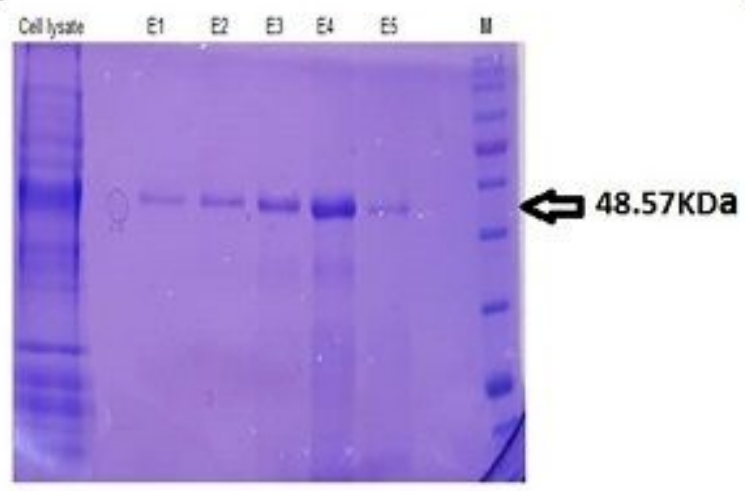

B

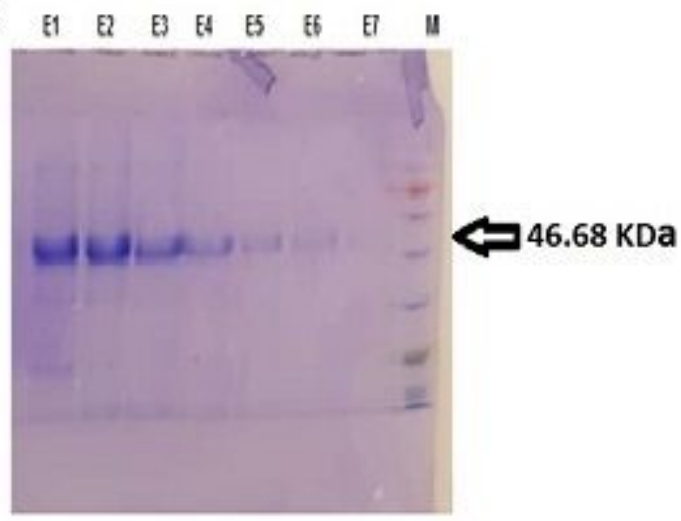

\section{Figure 5}

SDS-PAGE analysis of HPV16,18,6,11 E7-Tat (48.57 KD) and HPV16,18,6,11 E7 protein (46.68 KD) purification. (A): Lane $\mathrm{M}=$ protein marker (245 KD); lane E1-E5: purified fusion protein; cell lysate: soluble protein. (B): Lane $M=$ protein marker (245 KD); lane E1-E7: purified fusion protein.

A

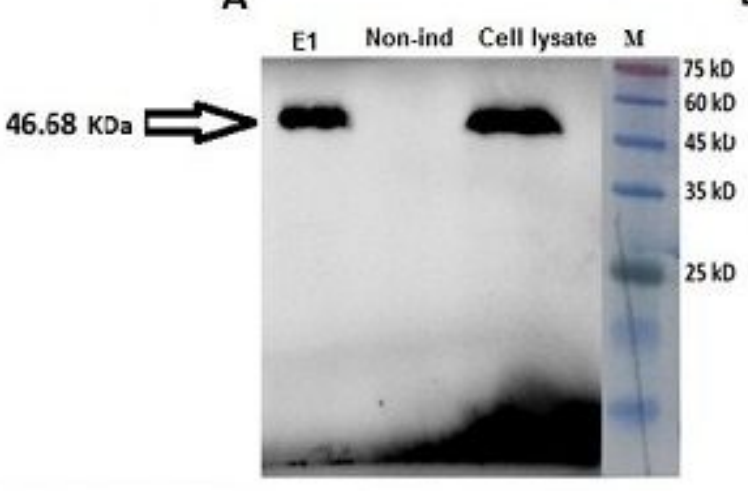

B

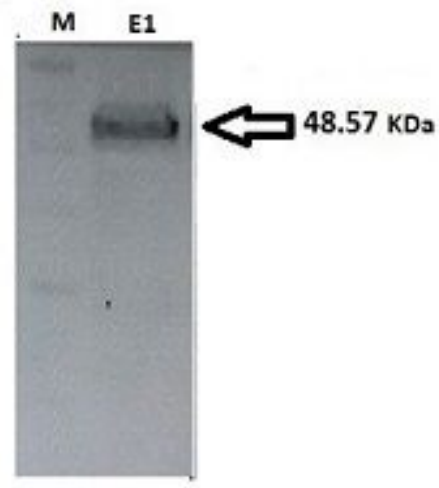

\section{Figure 6}

Immune identification by western blotting analysis of HPVE7-Tat (48.57 KD) and HPVE7 protein (46.68 KD) expression. (A): Lane $\mathrm{M}=$ protein marker (245 KD); lane E1: purified fusion protein; Non-ind (Before IPTG induction); cell lysate: soluble protein. (B): Lane $\mathrm{M}=$ protein marker (245 KD); lane E1: purified fusion protein. 

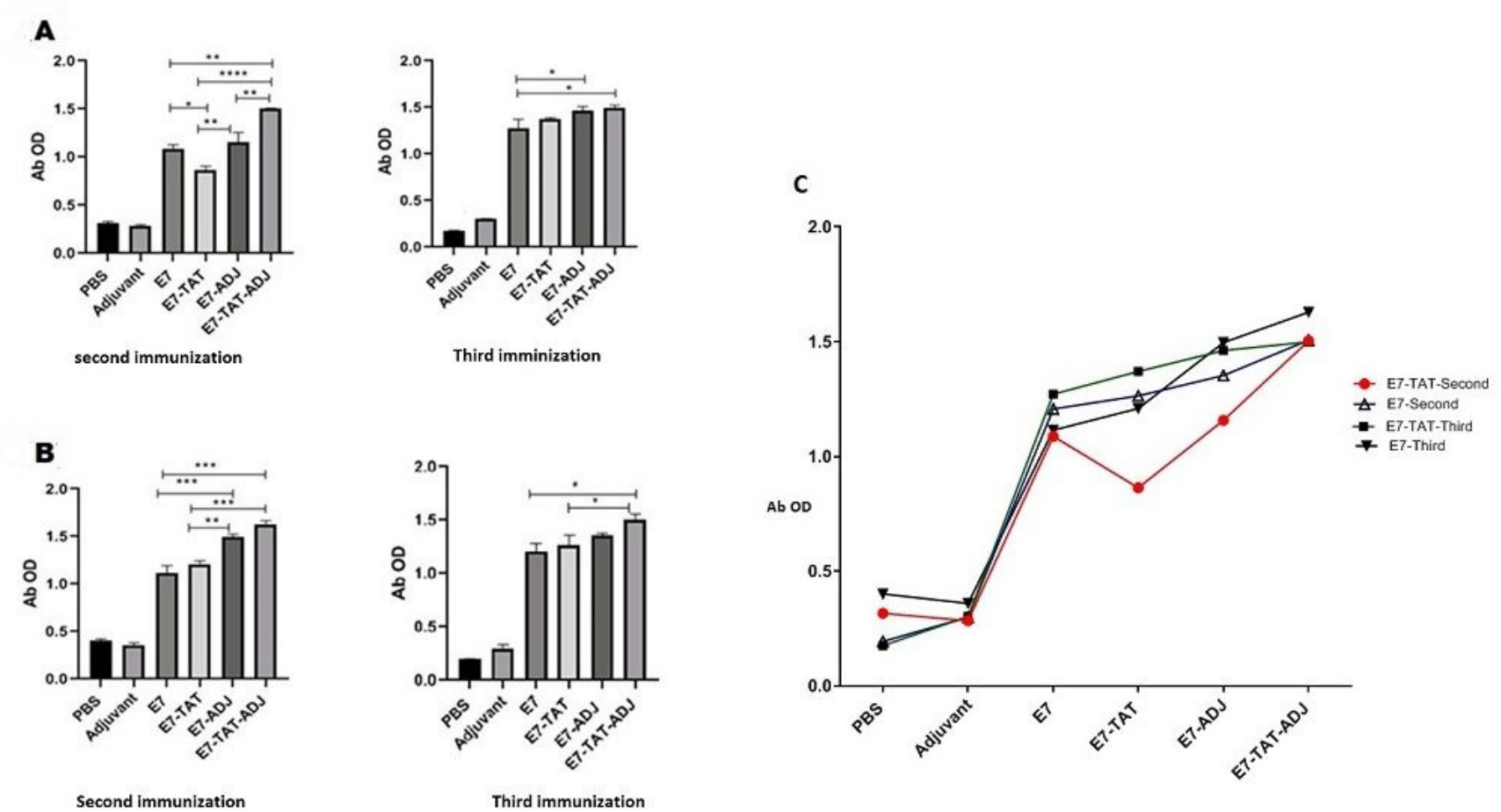

Figure 7

(A). Analysis of specific IgG response with respect to HPV 16,18,6,11 E7-Tat protein in per group of mice immunized with different component using ELISA after second and third immunization. Mice were immunized at $0,14,28$ days. IgG titer was detected by ELISA using 1:100 sera dilution. The secondary antibody was diluted 1:10000 in PBS. X-axis, sera dilution of different group; Y-axis, end-point titers in median (horizontal bar). $\left({ }^{*}=0.0246\right),(\star \star=0.0010),\left({ }^{*} * \star *=0.0001\right)$. (B). Analysis of specific IgG response with respect to HPV $16,18,6,11 \mathrm{E7}$ protein in per group of mice immunized with different component using ELISA after second and third immunization. Mice were immunized at 0, 14, 28 days. IgG titer was detected by ELISA using 1:100 sera dilution. The secondary antibody was diluted 1:10000 in PBS. X-axis, sera dilution of different group; Y-axis, end-point titers in median (horizontal bar). ( $\left.{ }^{*}=0.0246\right),\left({ }^{*}=0.001\right)$, $(\star \star \star=0.0002)(C)$. Comparison of specific IgG response with respect to HPV16,18,6,11 E7 and HPV16,18,6,11 E7 protein in per group of mice immunized with different component after second and third immunization. IgG titer was detected by ELISA using 1:100 sera dilution. The secondary antibody was diluted 1:10000 in PBS. X-axis, sera dilution of different group; Y-axis, end-point titers in median (horizontal bar). 


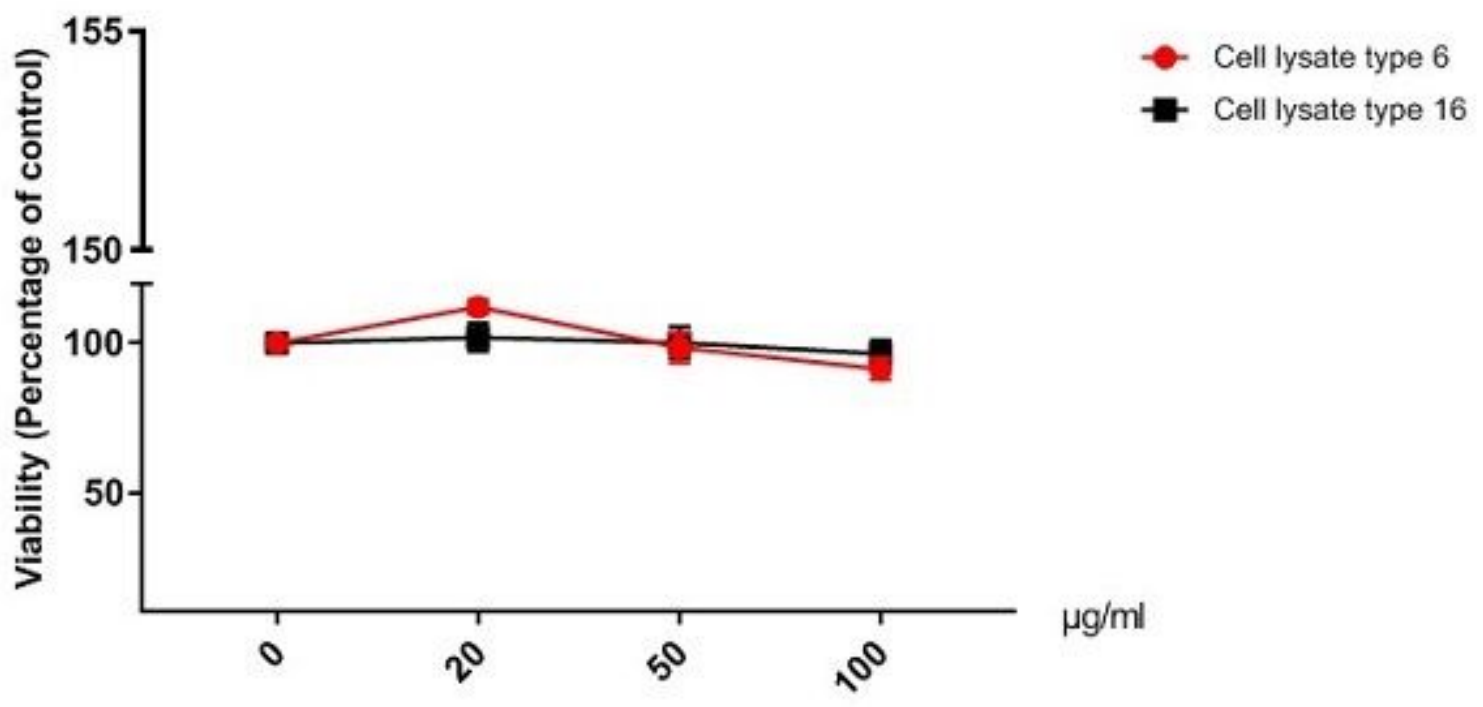

Figure 8

Splenocyte cell viability by the MTT assay ( $\left.{ }^{*} \mathrm{P}<0.05\right)$. HPV16 E7 and HPV6 E7 cell lysate $(10 \mu \mathrm{g}, 50 \mu \mathrm{g}$, $100 \mu \mathrm{g})$, splenocytes cells (negative control). Cells were incubated with different concentrations of each protein for $48 \mathrm{~h}$.

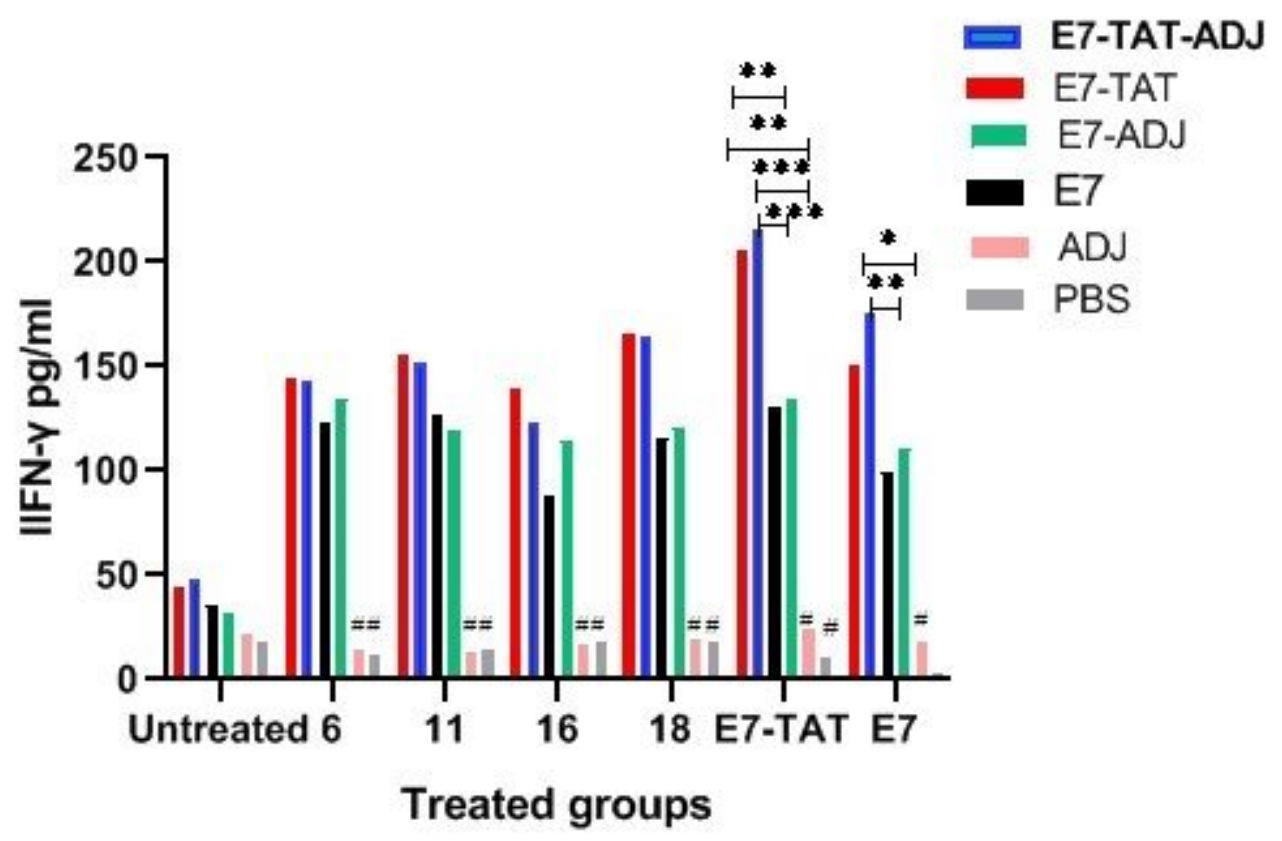

Figure 9 
Analysis of cellular immune response (IFN-y production): Splenocytes from mice were stimulated with HPV16, HPV18, HPV6, HPV11 cell lysates, E7-Tat and E7 protein in-vitro. The levels of IFN-y were

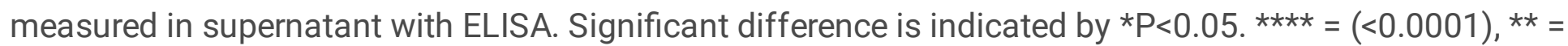
$(0.0073,0.0055,0.0027), \#=(<0.0001), \star \star \star=(0.0008,0.0004)$

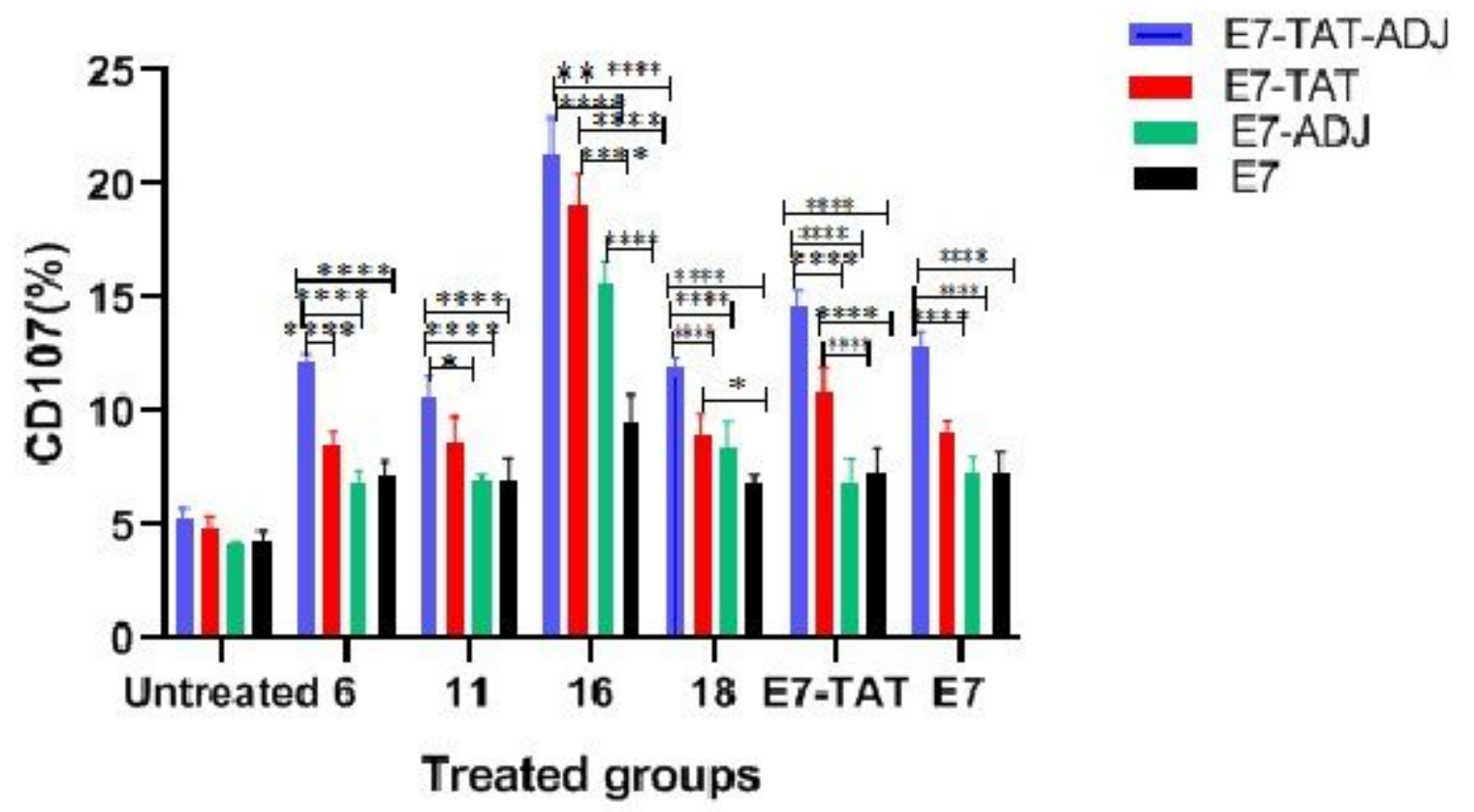

Figure 10

CD107 expression, percentage: Splenocytes from mice were stimulated with HPV16, HPV18, HPV6, HPV11 cell lysates, HPVE7-Tat and HPVE7 protein in vitro. The levels of CD107a expression were measured by FCM. Significant difference is indicated by $* P<0.05 . *=(0.0391,0.022), * \star=(0.0096), * \star \star=$ $(0.0003), * \star \star \star=(<0.0001)$. 


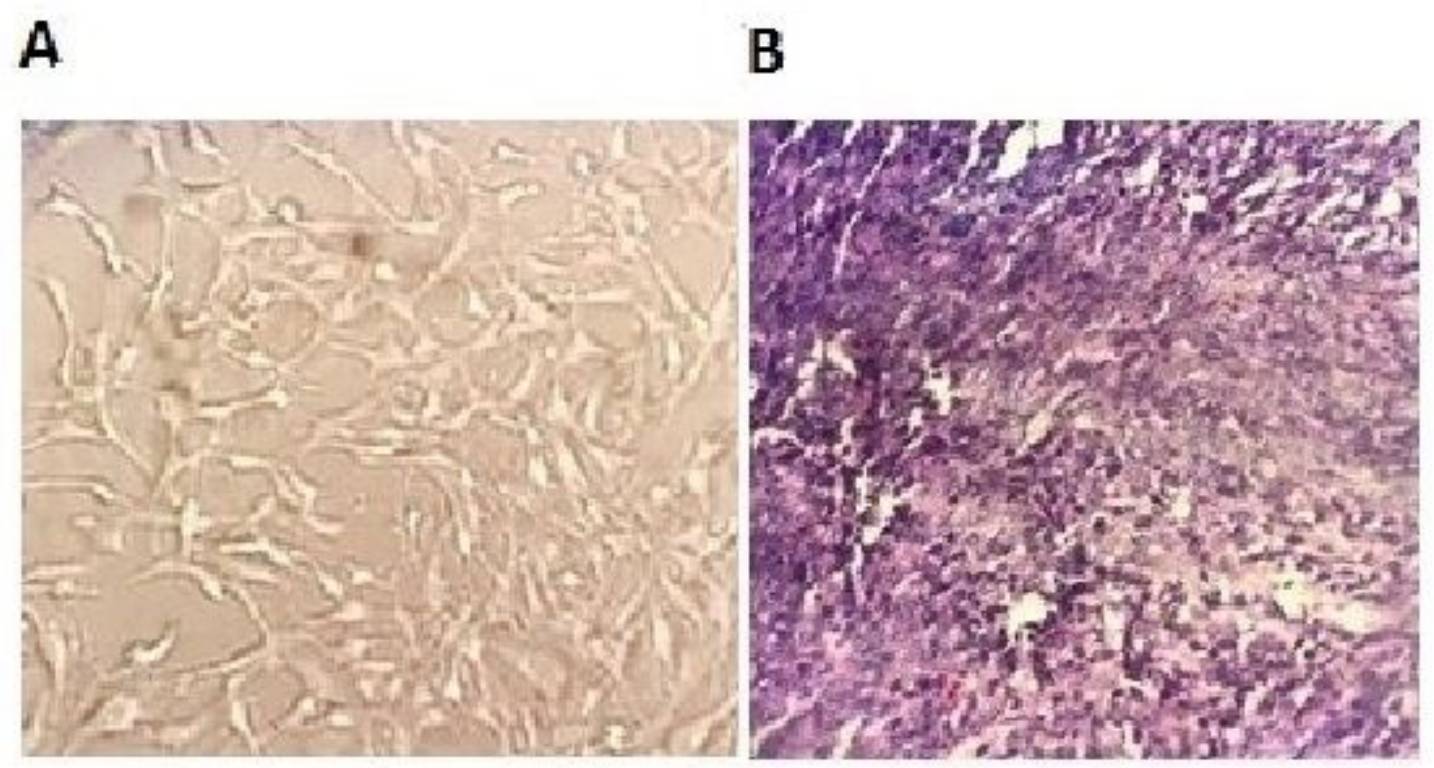

\section{Figure 11}

HPV16 E7-expressing TC-1 cell. (B): The original H\&E image shows the composition of tissue histopathology.
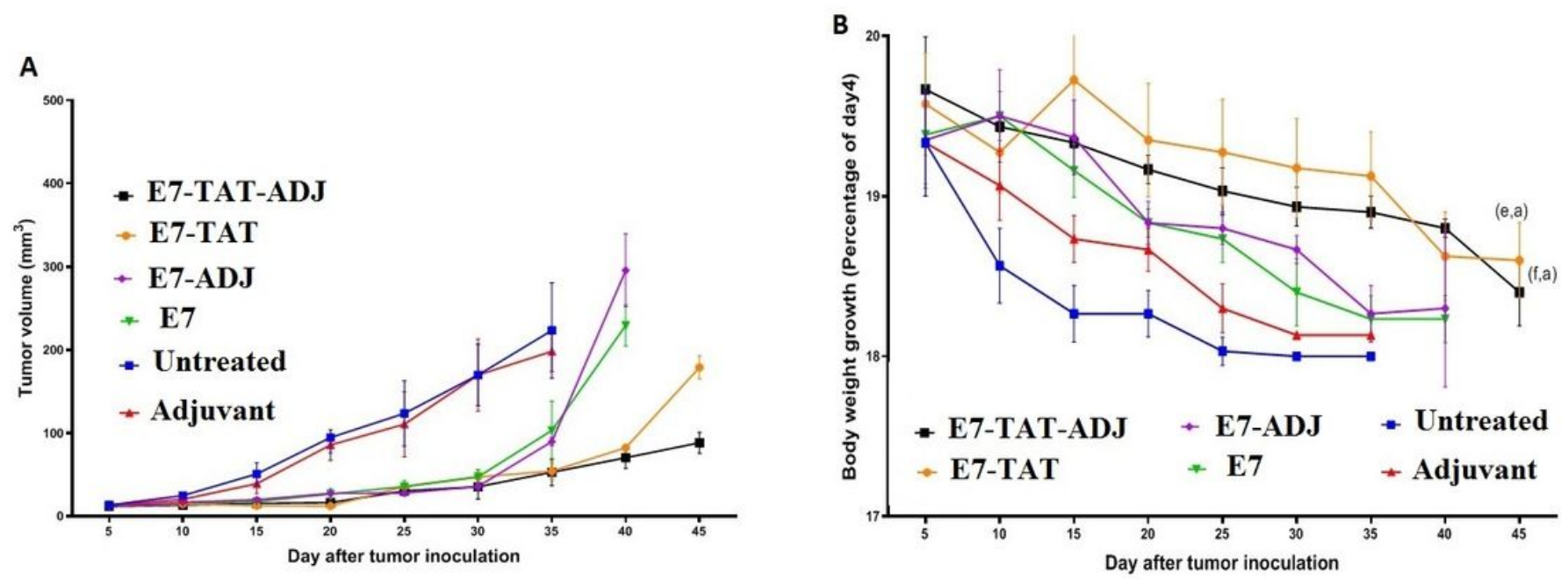

\section{Figure 12}

C57BL/ 6 mice $(n=4)$ were challenged with $3 \times 105$ cells on day 0 . when palpable tumors were detected, mice were vaccinated three times on day 0,14 and 28 with injection of E7-Tat, E7-Tat-Adj, E7, E7-ADJ, PBS and Adjuvant and followed for up to 45 days. The tumor volume $(A)$ and body weight were measured twice a week (B). 


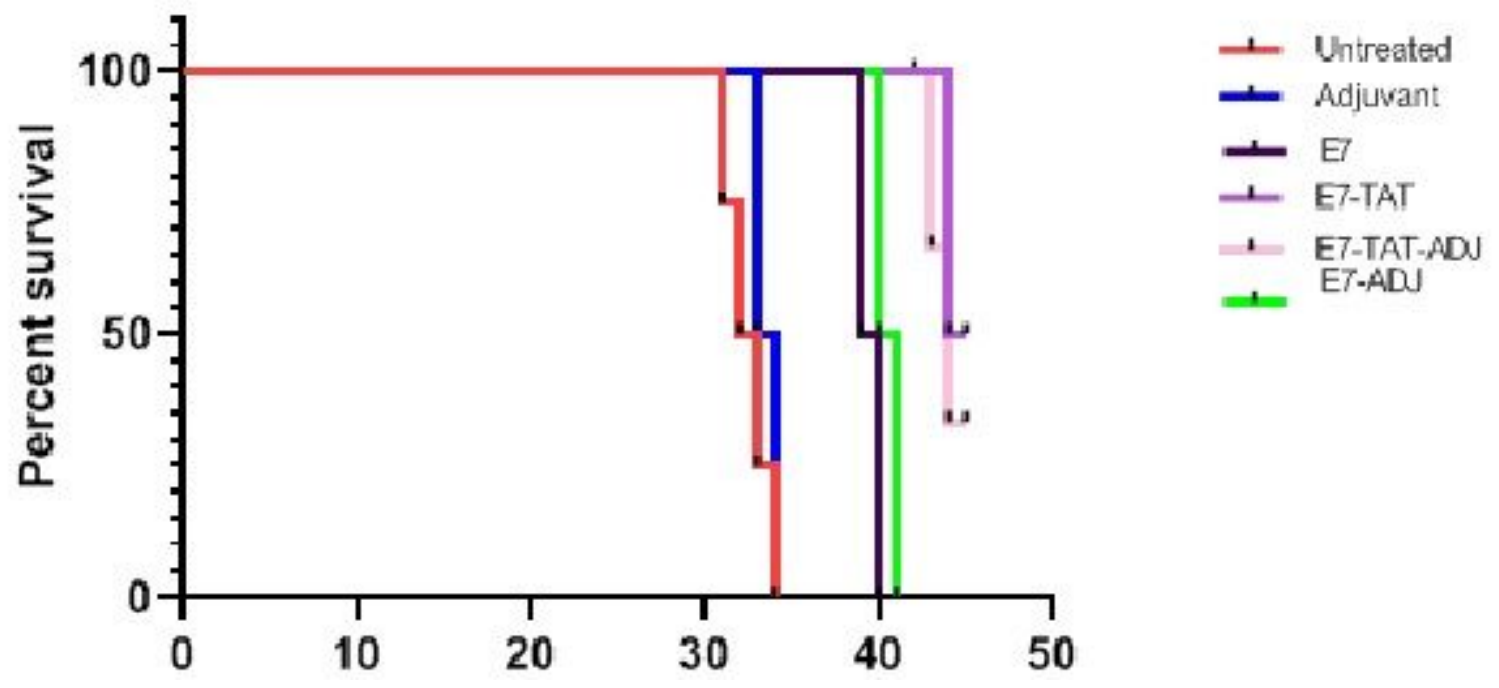

Figure 13

Percent survival curve indicated using the log-rank (Mantel-Cox) test. The survivals of animals were determined every day. Data with $P$ value $\leq 0.05$ were significantly different. 